\title{
HEAVY METAL CONCENTRATIONS IN THE SEDIMENT PROFILES OF THE ANTHROPOGENICALLY TRANSFORMED PLOCIDUGA RESERVOIR
}

\author{
ZAWARTOŚĆ METALI CIĘŻKICH W PROFILACH OSADÓW DENNYCH \\ ANTROPOGENICZNIE PRZEKSZTAŁCONEGO ZBIORNIKA PŁOCIDUGA
}

\begin{abstract}
The aim of the present study was to determine the level of contamination of the bottom deposits in the former lake Plociduga in Olsztyn by selected heavy metals $(\mathrm{Zn}, \mathrm{Pb}, \mathrm{Cr}, \mathrm{Cd})$. Today Plociduga is a transformed wetland ecosystem, surrounded by urbanized areas (residential housing, industrial development). The main point sources of pollution are the outlets of two storm water drains. The study was conducted in 2009. Samples of bottom deposit cores were collected in two separate parts (northern and southern) of the former lake. The study revealed very high concentrations of lead, zinc and chromium in the uppermost layer of the sediments in the part of the ecosystem fed by rainwater. The concentrations of the analyzed elements were substantially lower in deeper sediment layers and in the samples collected in the southern part of the ecosystem, not exposed to the direct pollutant inflow. The accumulation of heavy metals in the surface layers of bottom deposits is indicative of the poor ecological condition of the investigated ecosystem and increased human pressure resulting from progressive urbanization.
\end{abstract}

Keywords: transformed lake, anthropopressure, heavy metals, urban catchment

Water pollution and soil contamination caused by toxic substances poses one of the greatest problems in environmental protection. Heavy metals are specific pollutants - those non-biodegradable elements are accumulated in various land and water ecosystems [1-3]. Heavy metals reach aquatic environments as by-products of industrial activity, fossil fuel burning and traffic emissions [4]. Bottom deposits in water bodies trap the majority of heavy metals which form stable complexes with mostly organic matter. If sediment pollutants are not disturbed, deposit cores may offer a glimpse into the history of sedimentation of atmospheric pollutants and impurities from the catchment area [5, 6]. The concentrations of water-borne pollutants may fluctuate on a seasonal basis, subject to temperature, flow rate and precipitation, whereas bottom deposits are much less susceptible to the above factors [7]. For this reason, the concentrations of heavy metals deposited in water bodies are an indicator of external anthropogenic influences [1, 7, 8], and they

\footnotetext{
${ }^{1}$ Department of Land Improvement and Environmental Management, University of Warmia and Mazury in Olsztyn, pl. Łódzki 2, 10-719 Olsztyn, Poland, phone +48 895234314

*Corresponding author: andrzej.skwierawski@uwm.edu.pl
} 
illustrate environmental changes that are taking place in a given water body $[9,10]$. The bottom deposits of water bodies in urban areas are the subject of many research studies as the potential source of heavy metals that could be released into the aquatic environment [6].

The objective of this study was to assess the level of heavy metal contamination ( $\mathrm{Zn}$, $\mathrm{Pb}, \mathrm{Cr}, \mathrm{Cd}$ ) of bottom deposits in the bed of the former lake Plociduga in Olsztyn, and to determine the manner of pollutant sedimentation based on analyses of deposit cores.

\section{Materials and methods}

The investigated area was a basin-shaped depression formed by the bed of the former lake Plociduga [11] in the southern part of Olsztyn. The lake was drained by an open ditch feeding into the Lyna River in Olsztyn's residential estate of Mleczna. The basin has a total area of approximately 13 ha. It is filled with water in the northern part, which is separated from the remaining sections by a dam that serves as a pedestrian walkway. The entire area is densely overgrown with Phragmitetum australis rushes. The site is surrounded by residential buildings and industrial facilities (Fig. 1). The catchment area is situated in the proximity of the heavily trafficked Warszawska street, and two storm drains evacuate water from the road into the reservoir. Plociduga is extremely degraded due to its location, type of feed inflows and local morphometric conditions.

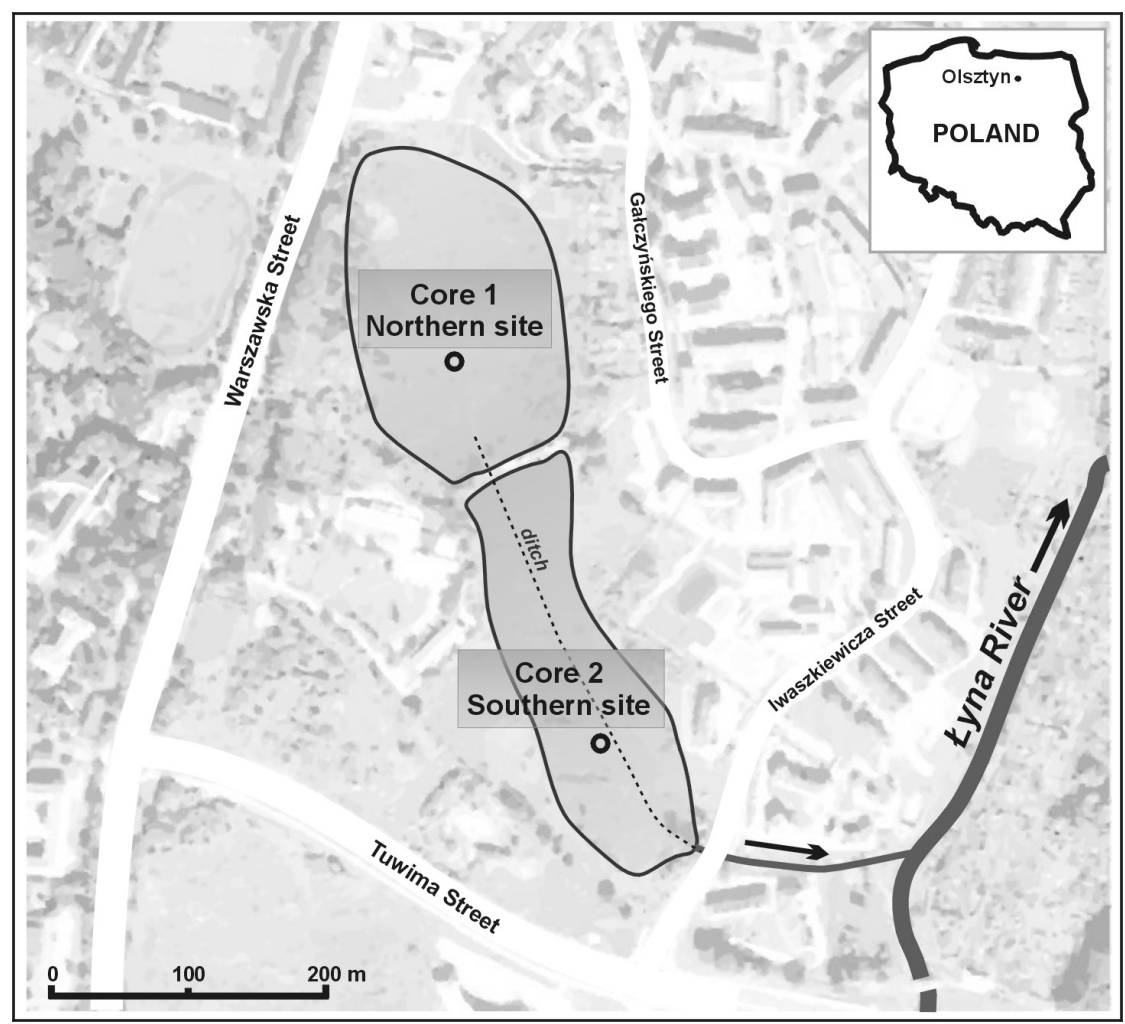

Fig. 1. Location of the research area and sampling sites 
Analytical samples were collected in January 2009 at two sites situated in the northern region of Plociduga (with an open water zone) and, for comparative purposes, also in its southern part, presently a water-logged wasteland. Deposits were sampled with the use of a core probe that supports the collection of material with intact structure. The cores with a thickness of $0.9 \mathrm{~m}$ (northern site) and $1.4 \mathrm{~m}$ (southern site) were split into $0.10 \mathrm{~m}$ layers for analytical purposes.

The total content of heavy metals, including cadmium, chromium, lead and zinc, was determined in sediment fractions with a particle diameter of $<0.2 \mathrm{~mm}$. Chemical analyses were performed in the laboratory of the Chemical and Agricultural Station in Olsztyn. The presence of the investigated elements was determined by atomic absorption spectrometry (AAS) in accordance with standard PB 01: ed1/28.008.1998. Samples were mineralized in a 4:1 mixture of nitric acid and perchloric acid. Bottom deposits were also analyzed to determine their bulk density, moisture content, organic matter content, nitrogen and phosphorus concentrations.

The reservoir's hydrochemical profile was developed based on analyses of water samples collected during eight sampling sessions in 2009. Water quality parameters were evaluated with the use of standard methods in the laboratory of the Department of Land Improvement and Environmental Management at the University of Warmia and Mazury in Olsztyn.

\section{Results and discussion}

The obtained data point to significant variations in the analyzed parameters of sediments collected from both parts of the reservoir as well as in deposit cores. Very high concentrations of heavy metals were noted in the surface layer of bottom deposits. Water quality surveys carried out in 2009 along the basin's drainage ditch revealed high levels of salinity, due to the inflow from storm water drains, as well as a high content of biogenic compounds (Table 1).

Table 1

Average values of water quality parameters in the northern and southern parts of Plociduga, based on 2009 data

\begin{tabular}{|l|c|c|c|}
\hline \multirow{2}{*}{\multicolumn{1}{c|}{ Parameter }} & \multirow{2}{*}{ Unit } & \multicolumn{2}{c|}{ Value } \\
\cline { 3 - 4 } & & Northern site & Southern site \\
\hline Dissolved oxygen & {$[\%]$} & 54.3 & 42.3 \\
\hline Reaction $\mathrm{pH}$ & - & 7.2 & 7.3 \\
\hline Electrolytic conductivity & {$\left[\mu \mathrm{S} \cdot \mathrm{cm}^{-1}\right]$} & 842 & 784 \\
\hline Total phosphorus & {$\left[\mathrm{mgP} \cdot \mathrm{dm}^{-3}\right]$} & 0.71 & 0.64 \\
\hline Total nitrogen & {$\left[\mathrm{mgN} \cdot \mathrm{dm}^{-3}\right]$} & 3.40 & 2.23 \\
\hline Chlorides & {$\left[\mathrm{mg} \cdot \mathrm{dm}^{-3}\right]$} & 124.8 & 85.0 \\
\hline Sodium & {$\left[\mathrm{mg} \cdot \mathrm{dm}^{-3}\right]$} & 77.0 & 49.5 \\
\hline
\end{tabular}

Plociduga is an example of a highly degraded water ecosystem that receives urban runoff. High salinity levels result mainly from the use of a road deicing agent, sodium chloride (salt), in the winter. Deicing salt is generally of low purity, and it may contain a significant amount (up to 5\%) of various additives, including heavy metals [12]. The above was demonstrated by a survey of 13 lakes in Minnesota, USA with high storm water runoff loads. In the above study, the lakes' average electrolytic conductivity reached 
$745 \mu \mathrm{S} \cdot \mathrm{cm}^{-1}$ in the winter and $612 \mu \mathrm{S} \cdot \mathrm{cm}^{-1}$ in the summer [13]. Plociduga's degradation can be attributed mainly to its salinity profile, as demonstrated by high concentrations of chloride and sodium, and electrolytic conductivity of $842 \mu \mathrm{S} \cdot \mathrm{cm}^{-1}$ in the northern site, the direct recipient of storm water, and $784 \mu \mathrm{S} \cdot \mathrm{cm}^{-1}$ in the southern site, which is mostly supplied with water from the northern part of the reservoir (Table 1). Plociduga is strongly degraded owing to its location and the inflow of storm water.

The physical properties of deposits sampled from the northern and southern parts of the reservoir were characterized by significant variability. The bulk density of deposits collected from the northern site increased from the surface $\left(1.22 \mathrm{~g} \cdot \mathrm{cm}^{-3}\right)$ to a depth of $0.5 \mathrm{~m}$ $\left(1.75 \mathrm{~g} \cdot \mathrm{cm}^{-3}\right)$. In this section of the core, organic matter content decreased from $36 \%$ d.m. at the surface to $6 \% \mathrm{~d} . \mathrm{m}$. in the $0.4-0.5 \mathrm{~m}$ layer (Fig. 2). In general, the organic matter content of bottom deposits is affected by a combination of factors, in particular ecosystem productivity and the inflow rate of allochthonous matter [14]. The value of the discussed parameter could be significantly lowered by the inflow of inorganic matter from the catchment area [15] which "dissolves" organic matter deposited in water bodies. In Płociduga, the deposit layer at the level of $0.5 \mathrm{~m}$ denotes a period in which the reservoir became a recipient of storm water discharges. The accumulation of this layer probably began in 1978 when the Warszawska street underwent major reconstruction. Deeper layers are characterized by lower density and a higher organic matter content, and they were built up during lake drainage which turned this water body into a water-logged field. In the southern site, peat-like deposits with more than $80 \%$ organic matter content of dry matter were found below surface formations with lower organic matter levels (Fig. 2). The above observations suggest that in the past, the southern part of the reservoir was a water-logged and overgrown bay of Lake Plociduga which connected this water body with the Lyna River. This configuration is shown in $19^{\text {th }}$ century maps of the area.
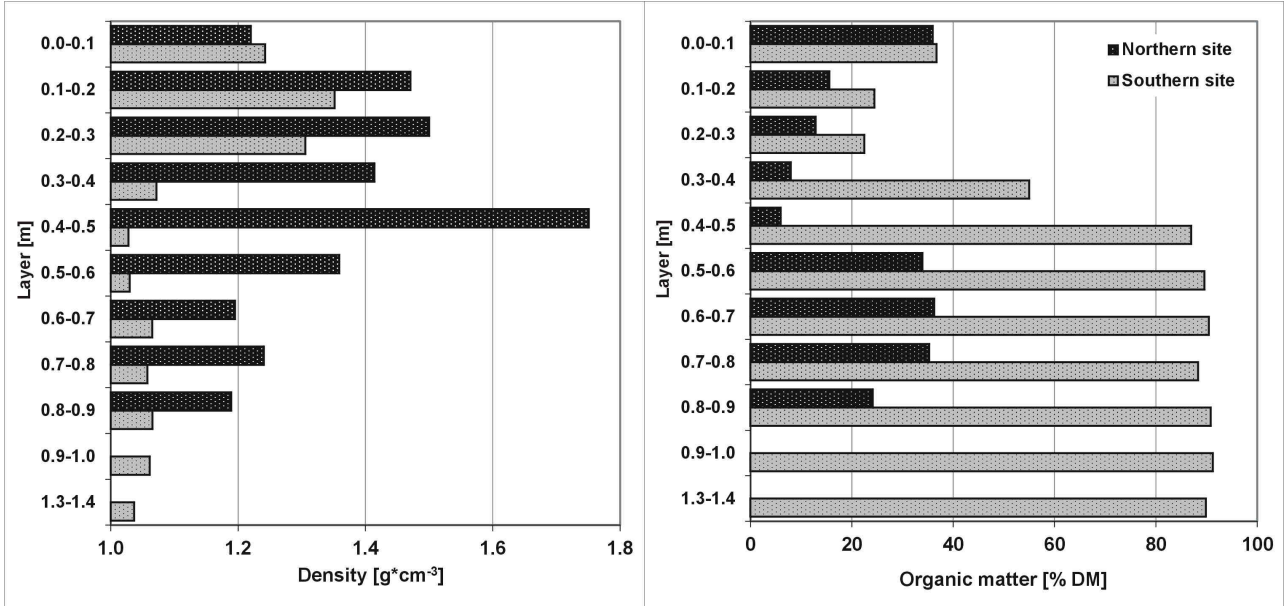

Fig. 2. Bulk density and organic matter content of bottom deposit cores collected from the northern and southern parts of Plociduga

Similarly to water samples (Table 1), deposit samples collected from Plociduga were also abundant in phosphorus. The highest phosphorus concentrations were reported in the 
surface layer, at $0.41 \%$ d.m. (Fig. 3). The noted P levels were nearly eight-fold higher in comparison with sediment samples collected from small water bodies [16]. Even the deeper and more phosphorus-deficient deposit layers in Plociduga revealed much higher phosphorus concentrations than rural ponds affected by point source pollution. In the southern site, phosphorus levels decreased with depth, reaching the values noted in the bottom deposits of small ponds subjected to high anthropogenic pressure.

Nitrogen concentrations in surface layers were determined at $0.90 \%$, and the noted level is characteristic of lacustrine deposits. In 68 small lakes of Central Europe [17], average nitrogen concentrations were observed at $0.70 \%$ of deposit dry matter. At a depth of 0.1 to $0.5 \mathrm{~m}$ in the northern part of Plociduga, nitrogen levels were low at $0.20 \% \mathrm{~d} . \mathrm{m}$. on average, which corresponded to a lower organic matter content of those deposits (Figs. 2 and 3). Contrary to phosphorus, nitrogen concentrations in peat-like deposits from the southern part of the reservoir were higher than in those sampled from the northern site, and they were indicative of high organic matter content (correlation coefficient of 0.91 Table 2).
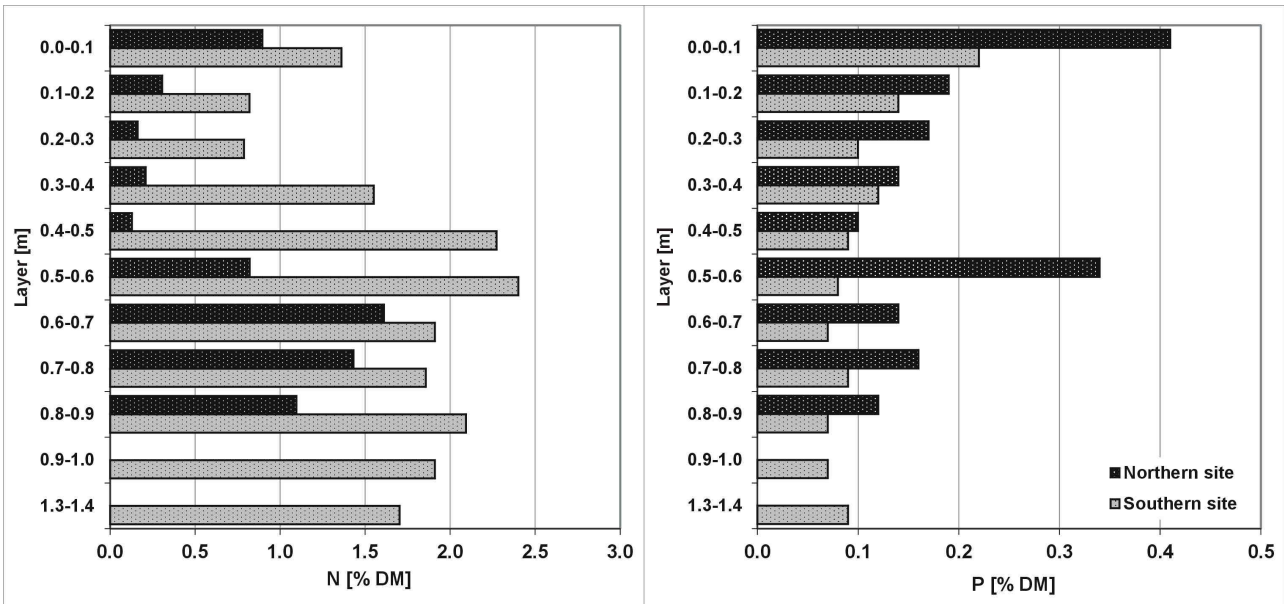

Fig. 3. Nitrogen and phosphorus concentrations in bottom deposit cores collected from the northern and southern parts of Plociduga

In general, anthropogenic pollutants, including heavy metals, have a vertical distribution pattern, ie their concentrations are higher in the top layers of deposits and they gradually decrease towards deeper layers of the profile. This structure reflects the global process of growing anthropogenic pressure from the $19^{\text {th }}$ century [5]. The concentrations of the analyzed pollutants decreased with depth mainly in the northern part of Plociduga (Figs. 4 and 5), which is the direct recipient of storm water discharges. In this section of the reservoir, pollutant levels were much higher than in the southern site. The top layers of deposit samples collected from the northern site revealed very high concentrations of lead (384 mg. $\mathrm{kg}^{-1} \mathrm{~d} . \mathrm{m}$.), zinc (982 $\mathrm{mg} \cdot \mathrm{kg}^{-1} \mathrm{~d} . \mathrm{m}$.) and chromium (73.7 $\mathrm{mg} \cdot \mathrm{kg}^{-1} \mathrm{~d} . \mathrm{m}$.). Maximum lead and zinc concentrations were more than ten-fold higher than in the bottom deposits of lakes in northern Poland. In a study by Bojakowska and Gliwicz [18], pollutant concentrations in the bottom deposits of lakes reached the following average values: 
$\mathrm{Cd}-0.78, \mathrm{Cr}-11.0, \mathrm{~Pb}-32.8$ and $\mathrm{Zn}-84.0 \mathrm{mg} \cdot \mathrm{kg}^{-1}$. Heavy metal concentrations were also significantly higher than those reported in the bottom deposits of small ponds [19], including rural ponds situated in the proximity of roads and subjected to point source pollution. Lead concentrations in the surface deposits of Plociduga were nearly ten-fold higher than those noted by Wróbel et al [20] in roadside soil samples. Such high levels of heavy metals in the studied deposits can most probably be attributed to the long-term accumulation of pollutants from the catchment area, in particular a busy road that evacuates storm water to the reservoir. The noted increase in pollutant concentrations from the level of $0.5 \mathrm{~m}$ towards the surface is most likely the result of intensified traffic, in particularly in recent years, whose effects can be observed in the top deposition layer (0-0.1 m).

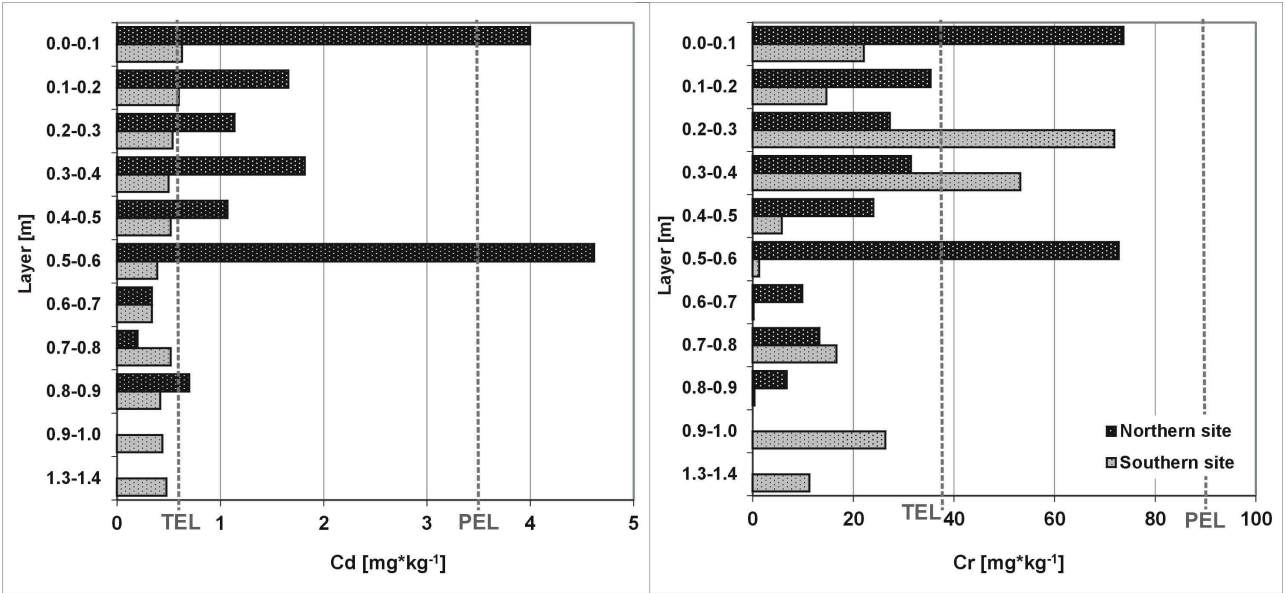

Fig. 4. Cadmium and chromium concentrations in bottom deposit cores collected from the northern and southern parts of Plociduga, with an indication of TEL and PEL levels (explained in the text)
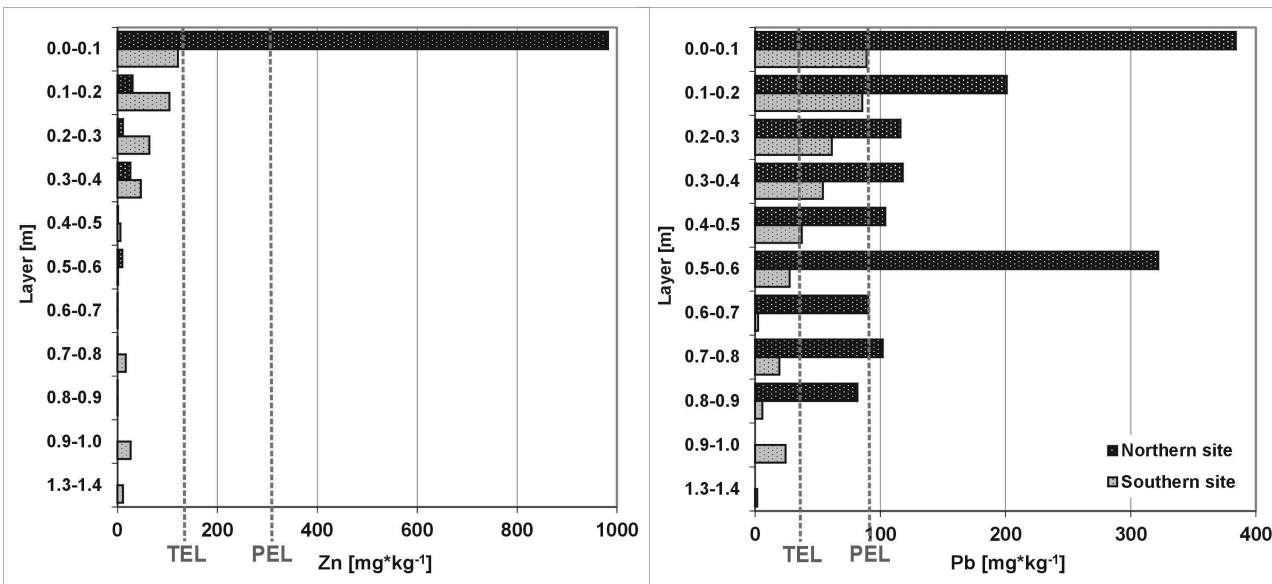

Fig. 5. Zinc and lead concentrations in bottom deposit cores collected from the northern and southern parts of Plociduga, with an indication of TEL and PEL levels (explained in the text) 
Significantly lower heavy metal concentrations were reported in deeper sediment layers and in the material collected from the southern part of the reservoir which is not directly supplied with pollutants. In the northern site, elevated levels of cadmium, chromium and lead were noted in the 0.5-0.6 m layer below the surface (Figs. 4 and 5). In respect of deposit density and organic matter content (Fig. 2) below that level, the physical properties of the sampled deposits were similar to peat. This layer probably indicates the moment when the northern part of the reservoir, which had been previously drained and used as a water-logged field, was repeatedly filled with water. The transitional period was characterized by intensified accumulation of pollutants supplied with storm water discharges.

Our results indicate that the concentrations of the analyzed heavy metals in bottom deposits decreased with depth, and that pollutants were accumulated simultaneously. The above is validated by highly significant coefficients of correlation in the values of $\mathrm{Pb}-\mathrm{Cd}-\mathrm{Cr}$ in the northern site and $\mathrm{Pb}-\mathrm{Cd}-\mathrm{Zn}$ in the southern site (Table 2). In the northern part of the reservoir, the 0.5-0.6 m layer was probably accumulated directly after the reconstruction of the Warszawska street and the construction of drains evacuating storm water to the reservoir. Zinc was the only heavy metal whose concentrations were not elevated in the studied layer (Fig. 5).

Table 2

Pearson's correlation coefficients between the values of indicators determined in bottom deposit samples from the northern and southern parts of Plociduga

\begin{tabular}{|c|c|c|c|c|c|c|c|}
\hline Variables & Density & $\mathbf{O M}^{1)}$ & $\mathbf{N}$ & $\mathbf{P}$ & Cd & $\mathbf{Z n}$ & $\mathrm{Cr}$ \\
\hline \multicolumn{8}{|c|}{ Northern site } \\
\hline OM & $-0.815 * *$ & & & & & & \\
\hline $\mathrm{N}$ & $-0.836^{* *}$ & $0.882 * *$ & & & & & \\
\hline $\mathrm{P}$ & -0.308 & 0.545 & 0.105 & & & & \\
\hline $\mathrm{Cd}$ & -0.033 & 0.246 & -0.186 & $0.894 * *$ & & & \\
\hline $\mathrm{Zn}$ & -0.296 & 0.364 & 0.082 & $0.760 *$ & 0.554 & & \\
\hline $\mathrm{Cr}$ & 0.021 & 0.238 & -0.221 & $0.924 * *$ & $0.978 * *$ & 0.627 & \\
\hline $\mathrm{Pb}$ & -0.160 & 0.414 & -0.033 & $0.975^{* *} *$ & $0.934 * *$ & $0.735^{*}$ & $0.962 * *$ \\
\hline \multicolumn{8}{|c|}{ Southern site } \\
\hline $\mathrm{OM}$ & $-0.938 * *$ & & & & & & \\
\hline $\mathrm{N}$ & $-0.912 * *$ & $0.911 * *$ & & & & & \\
\hline $\mathrm{P}$ & $0.610^{*}$ & $-0.696^{*}$ & -0.528 & & & & \\
\hline $\mathrm{Cd}$ & $0.688^{*}$ & $-0.748 * *$ & $-0.666^{*}$ & $0.803^{* *}$ & & & \\
\hline $\mathrm{Zn}$ & $0.867 * *$ & $-0.895 * *$ & $-0.805^{* *}$ & $0.892 * *$ & $0.839 * *$ & & \\
\hline $\mathrm{Cr}$ & 0.466 & $-0.648^{*}$ & $-0.659 *$ & 0.227 & 0.404 & 0.438 & \\
\hline $\mathrm{Pb}$ & $0.811^{* *}$ & $-0.898 * *$ & $-0.695^{*}$ & $0.830^{* * *}$ & $0.830 * *$ & $0.930 * *$ & 0.473 \\
\hline
\end{tabular}

Statistically significant correlations: * at $\alpha \leq 0.05$ and $* * \alpha \leq 0.01$

1) OM - organic matter

Evaluations of pollutant concentrations in bottom deposits should also account for their effect on the functioning of water ecosystems. Various assessment methods have been proposed [21, 22]. In line with a popularly applied method, the pollutants' threshold and probable effects on aquatic environments are evaluated with the involvement of TEL (Threshold Effects Level) and PEL (Probable Effects Level) indicators [23]. According to the above criteria, bottom deposits in the northern part of Plociduga significantly exceeded 
TEL values (threshold limit values for toxic elements) (Figs. 4 and 5). The lead content of the surface layer reached $421 \%$ of the PEL guideline value of $91.3 \mathrm{mg} \cdot \mathrm{kg}^{-1}$ [23]. Toxicity thresholds for aquatic organisms were exceeded in almost all layers of the deposit core, excluding at a depth of 0.6-0.7 $\mathrm{m}$ and $0.8-0.9 \mathrm{~m}$ (Fig. 5). The noted lead concentrations were radically high, despite the fact the analyzed element is generally characterized by very low mobility in catchment soils, which limits lead inflows into lakes. In catchment areas that are unchanged by human activity, the main source of lead is atmospheric precipitation [4]. In developed areas, impermeable surfaces and rapid evacuation of water via storm drains can dramatically change the distribution of pollution sources. Zinc and cadmium levels in surface deposits from the northern part of Plociduga were also significantly exceeded, reaching $312 \%(\mathrm{Zn})$ and $113 \%(\mathrm{Cd})$ of PEL guideline values. PEL limits were not exceeded in respect of chromium, and the levels of the analyzed heavy metals were also within the reference range in the southern site, although the noted concentrations were higher than TEL values in selected layers (Figs. 4 and 5).

Bottom deposits in Plociduga fail to meet soil and ground quality standards detailed by the Regulation of the Minister of Environment of 2002 [24]. The analyzed heavy metal concentrations $(\mathrm{Cd}, \mathrm{Cr}, \mathrm{Pb}, \mathrm{Zn})$ exceeded threshold levels, implying that the site is not entitled to statutory protection (for example, as part of a nature conservation area). Lead and zinc levels were even several-fold higher than the threshold values set for wasteland and developed areas ( $\mathrm{Pb}: 100 \mathrm{mg} \cdot \mathrm{kg}^{-1}, \mathrm{Zn}: 300 \mathrm{mg} \cdot \mathrm{kg}^{-1}$ - Fig. 5). The above could pose a serious zoning problem in the future.

The results of our study indicate that the evacuation of storm water to a former lake basin had adverse consequences for the reservoir's ecosystem. Natural basins, including marshes and water bodies, may be used as storm water retention reservoirs [25]. In its present shape, Plociduga supports the surface infiltration of water evacuated by storm water drains. The reservoir reduces the quantity of waste effluents discharged to the Lyna River through infiltration loss, evaporation and transpiration. Water retention in the reservoir also benefits the hydrographic structure by minimizing the risk of flooding in periods of heavy rainfall. Nonetheless, those functions have adverse effects on the reservoir's natural functions. Water bodies and wetlands play an important role in ecologically deficient urban areas, and the results of our study show that Plociduga's environmental function has been significantly impaired.

\section{Conclusions}

1. Heavy metal accumulation in the surface layer of bottom deposits testifies to the poor ecological condition of Plociduga and growing anthropogenic pressure due to progressive urbanization of the catchment area.

2. In the northern section of the analyzed site, which is supplied with storm water, threshold limits for aquatic environments were exceeded as regards zinc and cadmium concentrations in the surface layer $(0-0.1 \mathrm{~m})$ and lead concentrations throughout the deposit core to a depth of $0.9 \mathrm{~m}$. In the northern part of studied wetland area, bottom deposits failed to meet Polish soil and ground quality standards.

3. Owing to its location and landform features, Plociduga could significantly contribute to the urban landscape. In the light of legal regulations, the reservoir is strongly degraded, 
and it requires major reclamation before it can be effectively managed or included in a nature conservation scheme.

\section{Acknowledgements}

This study has been financed by the National Science Center, project No. N N305 304440.

\section{References}

[1] Radwar S, Kawalik W, Kornijów R. Accumulation of heavy metals in a lake ecosystem. Sci Total Environ. 1990;96:121-129.

[2] Dube A, Zbytniewski R, Kowalkowski T, Cukrowska E, Buszewski B. Adsorption and migration of heavy metals in soil. Pol J Environ Stud. 2001;10(1):1-10.

[3] Jumbe AS, Nandini N. Heavy metals analysis and sediment quality values in urban lakes. Am J Environ Sci. 2009;5(6):678-687. DOI: 10.3844/ajessp.2009.678.687.

[4] Renberg I, Persson MW, Emteryd O. Pre-industrial atmospheric lead contamination detected in Sweden. Nature. 1994;368:323-326. DOI: 10.1038/368323a0.

[5] Belzile N, Chen Y, Gunn JM, Dixit SS. Sediment trace metal profiles in lakes of Killarney Park, Canada: from regional to continental influence. Environ Pollut. 2004;130:239-248. DOI: 10.1016/j.envpol.2003.12.003.

[6] Shuchun Y, Bin X, Weilan X, Yuxing Z, Shijie L. Lead pollution recorded in sediments of three lakes located at the middle and lower Yangtze River basin, China. Quatern Int. 2009;208:145-150. DOI: 10.1016/j.quaint.2008.10.013.

[7] Boyle JF, Rose NL, Appleby PG, Birks HJB. Recent environmental change and human impact on Svalbard: the lake-sediment geochemical record. J Paleolimnol. 2004;31(4):515-530. DOI: 10.1023/B:JOPL.0000022549.07298.6e.

[8] Sobczyński T, Zerbe J, Elbanowska H, Siepak J. Chemical studies of sediments of the Góreckie Lake. Arch Environ Prot. 1999;23(3-4):125-136.

[9] Shuman B. Controls on loss-on-ignition variation in cores from two shallow lakes in the northeastern United States. J Paleolimnol. 2003;30:371-385. DOI: 10.1023/B:JOPL.0000007226.68831.e3.

[10] Gałczyńska M, Gamrat R, Pacewicz K. Influence of different uses of the environment on chemical and physical features of small water ponds. Pol J Environ Stud. 2011;20(4):885-894.

[11] Skwierawski A. The Causes, Extent and Consequences of Lake Drainage in the Olsztyn Lakeland in the $19^{\text {th }}$ and Early $20^{\text {th }}$ Century. In: Koc J, editor. Environment Alterations - Research and Protection Methods. Olsztyn: University of Warmia and Mazury; 2011:33-52.

[12] Marsalek J. Road salts in urban stormwater: an emerging issue in stormwater management in cold climates. Water Sci Technol. 2003;48(9):61-70.

[13] Novotny EV, Murphy D, Stefan HG. Increase of urban lake salinity by road deicing salt. Sci Tot Environ. 2008;406:131-144. DOI: 10.1016/j.scitotenv.2008.07.037.

[14] Kaplan MR, Wolfe AP, Miller GH. Holocene environmental variability in southern Greenland inferred from lake sediments. Quaternary Res. 2002;58:149-159. DOI: 10.1006/qres.2002.2352.

[15] Brown SL, Bierman PR, Lini A, Southon J. 10000 yr record of extreme hydrologic events. Geology. 2000;28:335-338. DOI: 10.1130/0091-7613(2000)028\%3C0335:YROEHE\%3E2.3.CO;2.

[16] Skwierawski A. Akumulacja fosforu w wodzie i osadach dennych jako wskaźnik poziomu degradacji stawów wiejskich i oczek śródpolnych [Phosphorus accumulation in water and bottom sediments as a indicator of degradation level of village and midfield ponds]. Zesz Nauk AE Wrocł, Chemia. 2004;1017:183-192.

[17] Müller B, Lotter A, Sturm M, Ammann A. 1998. Influence of catchment quality and altitude on the water and sediment composition of 68 small lakes in Central Europe. Aquat Sci. 1998;60:316-337.

[18] Bojakowska I, Gliwicz T. Wyniki geochemicznych badań osadów wodnych Polski w latach 2000-2002 [Results of water sediments geochemical studies of Poland in 2000-2002]. Warszawa: Wyd. IOŚ; 2003.

[19] Skwierawski A. Accumulation of heavy metals in bottom sediments in small water bodies characterized by various levels of degradation. Pol J Environ Stud. 2006;15(2a):494-502.

[20] Wróbel M, Chudecka J, Tomaszewicz T, Gałczyńska M. Contents of heavy metals in roadside soils and spatial distribution of metallophyte plant species on the roadsides of Szczecin Lowland. Ecol Chem Eng A. 2009;16(1-2):91-98. 
[21] Yao Z, Gao P. Heavy metal research in lacustrine sediment: a review. Chin J Oceanol Limn. 2007;25(3):444-454. DOI: 10.1007/s00343-007-0444-7.

[22] Perrodin Y, Donguy G, Bazin C, Volatier L, Durrieu C, Bony S, et al. Ecotoxicological risk assessment linked to infilling quarries with treated dredged seaport sediments. Sci Total Environ. 2012;431:375-384. DOI: 10.1016/j.scitotenv.2012.05.069.

[23] MacDonald DD, Ingersoll CG, Berger TA. Development and evaluation of consensus-based sediment quality guidelines for freshwater ecosystems. Arch Environ Con Tox. 2000;39:20-31. DOI: 10.1007/ s002440010075.

[24] Rozporządzenie Ministra Środowiska z dnia 9 września 2002 r. w sprawie standardów jakości gleby oraz standardów jakości ziemi [Regulation of the Minister of Environment issued 9 September 2002 on soil quality and land quality standards]. DzU 2002.165.1359.

[25] Ociepa E, Kisiel A, Lach J. Protection of surface waters from the discharge of rain-water sewage from sewage system. Proc ECOpole 2009;3(1):115-120.

\title{
ZAWARTOŚĆ METALI CIĘŻKICH W PROFILACH OSADÓW DENNYCH ANTROPOGENICZNIE PRZEKSZTAŁCONEGO ZBIORNIKA PLOCIDUGA
}

\author{
Katedra Melioracji i Kształtowania Środowiska, Uniwersytet Warmińsko-Mazurski w Olsztynie
}

\begin{abstract}
Abstrakt: Celem pracy było przeanalizowanie stopnia zanieczyszczenia wybranymi metalami ciężkimi ( $\mathrm{Zn}, \mathrm{Pb}$, $\mathrm{Cr}$, Cd) osadów dennych zbiornika Płociduga w Olsztynie. Obiektem badań było dawne jezioro, mające współcześnie charakter przekształconego ekosystemu mokradłowego. Zbiornik otoczony jest terenami zurbanizowanymi - zabudową mieszkaniową i przemysłową, a głównym bezpośrednim (punktowym) źródłem zanieczyszczenia są wyloty 2 kolektorów kanalizacji deszczowej. Badania przeprowadzono w 2009 roku. Rdzenie osadów pobrano z dwóch oddzielnych części zbiornika (północnej i południowej) i do celów analitycznych podzielono na warstwy o miąższości $10 \mathrm{~cm}$. Badania wykazały bardzo duże stężenia ołowiu, cynku i chromu w stropowej warstwie osadu w części zbiornika zasilanej ściekami deszczowymi. W głębszych warstwach osadu oraz $\mathrm{W}$ materiale pochodzącym $\mathrm{z}$ części południowej zbiornika stwierdzono znacznie mniejszą zawartość analizowanych składników. Akumulacja metali ciężkich w powierzchniowej warstwie osadu jest odzwierciedleniem złego stanu ekologicznego badanego obiektu oraz wzmożonej antropopresji związanej z postępującą urbanizacją terenu.
\end{abstract}

Słowa kluczowe: przekształcone jezioro, antropopresja, metale ciężkie, zlewnia miejska 